\title{
SEVEN SALUTARY WARNINGS FOR THE HUMANITIES: A BRIEF GLIMPSE INTO HOW THE LIBERAL ARTS HAVE FALLEN FROM GRACE
}

\author{
J. L. França Junior ${ }^{*}$ \\ University of Cape Town
}

\begin{abstract}
A decimation of the liberal arts is under way. The study of the humanities has steadily declined globally in the past decade along with a dire blend of internal and external crisis. On the one side, the dwindling financial aid and the ascendance of business and technology are playing a vital role in this ruin; on the other, the very soul of arts and culture is increasingly starved of the core values of liberal thought. The School of Humanities is being plagued by the rise of victimhood culture, dysfunctional pedagogical models, and an unprecedented weakened sense of commonwealth and freedom of expression. Extricating the humanities from this quagmire is no easy task, but it has to be done presently, as the supremacy of science and technology is no bill of rights for any nation. For the avoidance of this, the objective hereby is to afford a brief glimpse of the main reasons why the humanities have fallen from grace. Looking specially at the internal, self-sabotaging factors, seven salutary warnings will be issued as pertinent to departmental decision-making. Chiefly, not limiting the analysis of human nature and affairs to epistemological postmodern relativism and radical constructivist theories would signify a little progress. But more drastic changes have to be made. The School of Humanities needs to get rid, among other things, of its institutional stiffness and the vicissitudes of redemptive ideologies. A more diversified curriculum and a politically balanced faculty have to be pursued. And the Socratic method of learning and teaching could work as an antidote to the disciplinary malaise of today's academy.
\end{abstract}

Keywords: Higher Education. Humanities. Intellectual Ideas. Campus Life. Political Challenges.

What does it mean to be a self-conscious animal? The idea is ludicrous, if it is not monstrous. It means to know that one is food for worms. This is the terror: to have emerged from nothing, to have a name, consciousness of self, deep inner feelings, an excruciating inner yearning for life and self-expression - and with all this yet to die.

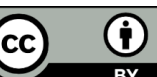

Esta obra está licenciada sob uma Creative Commons - Atribuição 4.0

\footnotetext{
* The author holds a BA degree in Translation and Interpreting Studies from the University of Brasília (19992003), an MA degree in English Language and Literature from the University of Cape Town (2007-2009), and is currently applying for admission to a Ph.D. program at the Northwestern University's English Department. Email: frantzajr@gmail.com.
} 


\section{Intro}

As the raging sea of political horrors hits us harder day after day, the humanist debate in the academy reaches a dead end in two corners - the one: a curious absence of down-to-earth learning and teaching initiatives that can cope with so many complex social, political and cultural issues, either locally or globally; the other: an overabundance of simplistic hype, mindless vitriol and false analogies that adds to the confusion of obsessive daydreams about institutional revolutions that will eventually free all men from the shackles of domination once and for all. No matter how much we are affected by the wider context of challenges, trivial or scary, facing Western democracies in the 21 st century, my fellow humanists have nothing more nourishing to offer than multicultural pieties, utopian illusions, victimhood paranoia, and an immature aversion to tradition and human nature in all its forms. Unfortunately, this appears to be a weakened and impoverished understanding postmodern humanists have of the relationship between politics, morality and ethics. In the departments, whole disciplines today build upon a fundamental intellectual abdication to evidence and experience. Scholars who play a prominent role in the establishment resort to mind-boggling jargon and obscurity to defend their bogus claims against common-sense truths. Their subversion of hope by utopianism and of free politics by the partiality of dominationresistance justice inspires little confidence in the future.

Overall, my fellow humanists have become used to adapting their rhetorical devices to the sweeping forces of pedantic speech, obscure formulae, magical thinking and redemptive airs, all of which based on a crude mix of jargon-ridden prose and socialist Newspeak on liberation and social justice. We have entered the magic circle of politics as wish-fulfilment.

I wonder how so many fellows still keep failing to test their political thought against political reality. I take the belief that this dereliction of academic duty to impart knowledge on the basic accounts of human nature and affairs is now so tenacious in the liberal arts studies because a highly sophisticated theoretical apparatus allows it to take roots. This theoretically volatile machine combines erudition and brilliance of style but is usually built around an inexplicable shrine. It is driven, by and large, by two of the greatest intellectual bankruptcies of the post-Marxist era: (1) the assumption that the world is divided between "oppressors" and "oppressed", and (2) the belief that we are all unique fruits of culture, and thus biology and genetics play no role in our urges and behaviour, still less so in economic and political 
development. This sophisticated theoretical bankruptcy has been impairing the study of the humanities for far too long. The thing seems now to be reaching a boiling point.

In the course proposals, classical ancient, conservative, and liberal thinkers are virtually non-existent. Conversely, the syllabi are repeatedly and conscientiously filled with "progressive" ideas and pro-Marxist theorists. Censoring books and ideas that do not fit the prevailing groupthink of what a progressive agenda should be is a recurrent sport in many departments. Much, I believe, to the discontent of a memorable left-winger who once warned of the dangers of political language as it is "designed to make lies sound truthful and murder respectable, and to give an appearance of solidity to pure wind" (ORWELL, 1968, p. 359). So I sit there pondering, is there any College of Humanities and Social Science on Earth where one can embrace subjects in history, languages, literature, the arts, philosophy, or sociology without having to be brainwashed by the moral sermons that routinely go under the banner of cultural-Marxist humanism, politically correct lunacy, and the hypocrisy of multiculturalism? The answer is... laconic, even disheartening. Judging from my own experience in the lecture halls and the things described in books and articles on the topic, the scenario in Europe (the United Kingdom, especially) and in the United States looks even more dramatic than in Brazil.

\section{Seven salutary warnings}

In what follows, I will attempt to compile some current events involving campus life and the intellectual malaise in the liberal arts. My purpose here is twofold: (1) to discuss alternative teaching and research aptitudes that can counterweight the epistemological postmodern theory that has left a trail of havoc across the humanities, and (2) to defend, through a couple of salutary warnings, human nature (and universals), the Socratic method (maieutic), non-contingent moral values, among others, as core values for the liberal arts, and against the ethical relativism that understands, accepts and forgives everything. Hence, I wish to further this study by going on to a précis of a recent article by Nick Cohen, a journalist for The Spectator, in which he discusses the detrimental effects of thought policing in the academy.

Cohen points out that, in the United Kingdom, the number of universities legitimately regarded as a "free space" - or a space for free debate where one can hear what one does not expect to and say whatever one wishes - is vanishing in the name of "safe spaces." Traditionally meant to be the place that blows away the cobwebs between the students' ears, the university used to be a space that gives the students a sense of freedom 
from the pressures of conformity and old conventions, before they have to adhere to the codes of silence of the workplace. This is not so true anymore. Cohen (The Spectator 2016) holds that "there's a fair chance that universities would be among the most servile and conformist institutions in Britain." The thought police on campus is raising voice against, bullying and vetoing any debate they disagree with. Cohen depicts an ongoing inversion of values according to which legitimacy and primacy are given to obscurantist ideas, whereas any "unpleasant" opinion is tainted as the object of the communal scorn:

\begin{abstract}
Human rights speakers are branded as racists and vile, whilst speakers who advocate for FGM practices and theocratic rule are applauded as intellectual heroes. In other words, and not for the first time in history, the far left is allied with the far right, and drags the soggy centre along whimpering behind it. It is grimly fascinating watching often angry and occasionally baffled students come to terms with the obscurantism around them....The most unfortunate and depressing aspect of the US vs THEM narrative permeating through universities today, is that it fails to grasp the fact that most people actually have the same goal in mind: to create a world in which no one is discriminated against for who they are. (COHEN, The Spectator 2016)
\end{abstract}

Certainly, any faculty or student is free to advocate for multiculturalism, but they should be no less than worried about the violations of intellectual freedom in higher education. Cohen is of the opinion that this is a serious issue at least for two reasons:

The idea of a university as a free space rather than a safe space is vanishing. This is a profoundly conservative development. The only people I can imagine welcoming it is the type of hard-headed businessman who says the point of education is to train the young to work not argue. Then there is the question of what will happen to all these barking martinets when they leave and join the establishment. Whatever poses they strike now, we will find that they fit in all too snugly. (COHEN, The Spectator 2016)

Traditionally linked to creativity, oratory, philosophical enquiry and critical thinking, what is the future of the humanities if the mundane interchange of ideas through consistent argumentation in a debate is to be banned completely? This PC phenomenon of progressive fanaticism was described in an earlier article also published in The Spectator. In 2014, Brendan O'Neill showed how a generation of PC-driven Stepford students were silencing diverse or daring thinkers at Britain's other famously prestigious universities. In the zealots' minds, to control the world of words and ideas in which they live is a kind of duty. O'Neill warns that this might mean "the victory of political correctness by stealth," which is a catastrophe, for the universities are being turned into "breeding grounds of dogmatism" (O’NEILL, 2014).

On the other side of the Atlantic, we hear from constitutional lawyer Greg Lukianoff and social psychologist Jonathan Haidt that "something strange is happening at America's 
colleges and universities." And what is it? So they supply us with the answer up-front: "A movement is arising, undirected and driven largely by students, to scrub campuses clean of words, ideas, and subjects that might cause discomfort or give offense" (LUKIANOFF; HAIDT, 2015). The authors bring forward the oversensitiveness of the American pupils by explaining the emergence of two obscure terms in the US campus parlance. One is microaggressions, which means malicious small actions or word choices like stating things such as "America is the land of opportunity" and "I believe the most qualified person should get the job," or asking "Where were you born?" to an Asian American or Latino American. The other is trigger warnings - i.e. alerts that professors should issue if some provocative content in a course programme might elicit negative emotional responses in the enrolled student. Examples? Some students may feel strong emotional arousal with the racial violence in Chinua Achebe's Things Fall Apart or the misogyny and physical abuse in F. Scott Fitzgerald's The Great Gatsby; hence the reason for the warnings so that those who have been victims of racism or domestic violence can choose to avoid the reading assignments. Trigger warnings can also include Virginia Woolf's Mrs. Dalloway for suicidal inclinations and Ovid's Metamorphoses for sexual assault.

This protective academic climate bordering on a surrealist Newspeak, as we shall see, poses significant threats to professorship, scholarship, and the general quality of universities. It is hard to know exactly why the phenomenon has burst forth so strongly in the past few years. In the United States, Lukianoff and Haidt (2015) reckons this compulsion arises from a mix of things like changes in the interpretation of federal antidiscrimination statutes, generational shifts, zero-tolerance policies, growing political polarization between Republicans and Democrats, and social media crusaders shifting the balance of power between students and faculty. Anyhow, the authors focus on this question: "What exactly are students learning.... in a community that polices unintentional slights, places warning labels on works of classic literature, and....conveys the sense that words can be forms of violence that require strict control by campus authorities, who are expected to act as both protectors and prosecutors?" They choose to seek an answer in terms of common cognitive distortions such as fortune-telling, overgeneralizing, inability to disconfirm etc. For them, higher education has been embracing "emotional reasoning" and this is dominating many campus debates. In practical terms, the Socratic method of teaching - which fosters critical thinking and discomforting thoughts - is being replaced by emotional reasoning teaching and vindictive protectiveness. This latter method, according to them, coaxes students to think in 
more-distorted ways and therefore prepares them poorly for professional life and engagement with ideas, values, and speech of the other side. Due to a campus culture devoted to policing speech and punishing anyone who interferes with that aim, the harm achieves not only democratic values but it is also likely to cause students emotional discomfort, depression and anxiety. So grim was the picture by late August 2016 that the University of Chicago Dean of Students decided to issue a letter to incoming freshmen telling them that the university does not support "trigger warnings," nor cancel speakers whose topics might be controversial, nor condone the creation of intellectual "safe spaces" (VIVANCO; RHODES, 2016).

How this rare breed of banning and bullying practices spreads on campus is a mystery. Where does the compulsion to discipline works of literature and curb the right to free speech come from?

With the birth of modern West by the end of 18th century, the principle of the rule of law only prohibits what can destroy or limit the freedom of others. Modern commonwealth seeks a balance between common good and individual rights. Our limit is the Constitution: that which is not prohibited by law is our right to do, or to say. But even with all those legal rights officially ushered in, there is no guarantee that life will be easier if we live in a liberal democracy. In fact, democracy is unavoidably loud, rude and a bit bonkers too. As is well known, the Republic does not end the conflict between different parties in a society; rather, democratic institutions are there to defuse tensions and restrain power struggles among the groups, settling their differences through the rule of law instead of coming to blows. In $A$ Letter Concerning Toleration, John Locke regards the toleration to those that are of different opinions as the chief liberal value. And not to perceive the necessity and advantage of it is pure blindness. "If this be not done," he argues (LOCKE, 1751, p. 244), "there can be no end put to the controversies that will be always arising between those that have, or at least pretend to have, on the one side, a concernment for the interest of men's souls, and, on the other side, a care of the commonwealth." So what now, when a generation of coddled students think their emotional feelings entitle them to invalidate other people's lived experience and freedom of expression?

Regrettably, the current misplace of the humanities with a more liberal and pluralist footing only help exacerbate the problem. The study of humanities has been seized by a melancholic shiver of traumas and oppression. Programs narrow down the knowledge production to issues invariably dedicated to Marxist-inspired critical theory, anti-capitalist sentiments, radical constructivism, victimhood talk, and political correctness. The last time 
there was a pugnacious air in the US about political correctness on campus was in the late 1980s, when Allan Bloom's The Closing of the American Mind came out. Bloom (1987) sought to investigate how higher education was failing democracy and impoverishing students' mind. He complained of the contemporary student talks as if there was no such thing as truth or falsity, right or wrong, since these students were up to make up their own values. However, if the debate in the late 1980s and early 1990s concerned a stronger idea of empowerment, challenging the cannon, and greater diversity on campus, now this speechpolicing phenomenon seems to be more related to human fragility, psychological frailty, and self-fulfilling prophecies. But why would a humanities student wish to shirk human fragility instead of pining it to the bones?

The engagement with victimhood, agency, power, and oppression in today's academy has become a big fetish in the liberal arts departments. The idea began to take shape with the 1960s deconstructive moves, which stem from the postmodern critiques of thinkers like Foucault, Lyotard and Derrida. These intellectuals contributed to create a conceptual paranoia about the "structures of domination" in which suspicion against traditional authority and institutions reigns. Much of this theoretical framework is devoted to "deconstructing" customs, values, law, hierarchy etc. New postmodern critiques pay increasing attention to issues of agency and power (and empowerment), domination (oppressors) and resistance (oppressed), and cultural constructivism. Despite mounting evidence to the contrary, postmodern radical cognitive constructivists claim that mind is wholly a product of culture, and therefore the idea of objectivity would be seen as futile at best, ethnocentric and politically hostile at worst.

Even if the issues raised by postmodernism may at times have their merits - such as the question of subjectivity and objectivity, authority and authorship, and power in culture this theoretical approach should be taken with a pinch of salt or read in conjunction with a mix of contemporary and classical works. Postmodernism alone cannot be - and will never be - the foundational basis for a fair and full examination of the conflicts that accompany the making of society and its social fabric. But then, the postmodern body of thought is the sole source of inspiration for many professors in the humanities today, especially in the Area Studies.

In a 2012 homage book to Bloom's title entitled The Victims' Revolution: The Rise of Identity Studies and the Closing of the Liberal Mind, cultural critic Bruce Bawer went on a research through a miscellany of key works, curricula, and conferences in the Area Studies. 
He found out that the study areas professors tend to rely on cryptic in-group language, meaningless abstract riddles, and nearly impenetrable "theory" to sound academically sophisticated. He drew attention to the dull and unreadable prose devoid of any effects on clarity and grace, the pseudo-intellectual parlance, and the grandiose posturing that saturate these disciplines, in which grossly misleading claims are taught as facts. The US progressive academy, to put it bluntly, has become a place of reactionary ideology and political rendezvous. I will take the liberty to present my own summary of his findings in the next couple of lines.

Identity studies courses are taught according to one or more of the following types of tutorial: (1) Race, or Chicanos/Latinos/blacks vs. racist whites/capitalist structure. But no mention of the many scientifically-based studies revealing our predisposition to segregate, as well as the artificiality and insignificance of the divisions we create in our own minds to put that to practice; (2) Gender, or women vs. patriarchal, macho, sexist men; (3) Class, or enthusiasm for second-hand Marxism. The Marxist dialectical materialism, though obsolete and lacking vitality nowadays, is being mixed with samples of Adorno, Foucault, Bourdieu and others, to inspire a new generation of thinkers. Yet no mention is made of the estimated 100 million victims crushed under the juggernaut of communism in Asia, Africa, and Eastern Europe; (4) Disability, not from a physical or biological but from a rights standpoint. As the author explains, “what disables disabled people isn't their disabilities but white men, capitalism, and all the other usual suspects" (BAWER, 2012, p. 309); (5) Sexuality, mostly gender minorities and queer-related topics. In time, it is necessary to "deconstruct" heteronormativity since heterosexuality is a "norm" imposed by sexist society; (6) Fat Studies, for beauty is yet another socially constructed form of oppression, and the idea of an obesity epidemic is a creation of irresponsible media, and so on. One can get a $\mathrm{PhD}$ degree in many of these areas and sub-areas.

Taken to extremes, this leads to what critic Camille Paglia (ReasonTV, 2015) calls “institutionalized whining" - you can say playing the victim's card and blaming Western civilization and capitalism for utterly everything seems to be a common denominator in these fields of studies, a conclusion which makes them pointless. Under the spell of this wretched influence, I have witnessed humanities students in Brazil branding authors like Gilberto Freyre and Monteiro Lobato as "racists" without having read a single line of their work. Obviously, it is not about dismissing upfront the notion of class, race and gender - a kind of holy trinity in contemporary human sciences - or even avoiding discussing it academically. 
One could (and should) disagree on how to tackle these issues, which is not the same as denying the existence of such problems. Notwithstanding, in the chaotic sound and fury of victimhood culture, a sort of theoretical monomania or dogmatic belief has become a rule.

It is also a problem of presentism. As the study of the humanities has become ever more fragmented, a comprehensive view of sociohistorical transformations across a time span of several millennia was lost somewhere. Over time the ability to meditate upon the moral and ethical needs of a community in a given period has sunk very low. The ideas of subverting hegemonic norms and fighting for absolute freedom, on the other hand, have flourished. All these subversive good intentions would lead to a poor capacity to discuss in great detail the shadowy picture of human nature in its fallen and unregenerate state, and in its moral aspects from the rest of nature. A huge question mark for any humanities research is this: Is evil intrinsic to human beings?

There are three traditional philosophical stances on human nature: that of Thomas Hobbes, who asserts that the natural state of man is bestial and evil; that of Jean-Jacques Rousseau, who sees us as naturally and innately good and it is civilization that turns us into a "beast"; and that of the British empiricists (Locke, especially), who claim human beings are born a tabula rasa onto which experience imprints itself through social institutions. Yet in a Darwinian light, all these claims can be seen as religiously motivated, based on a theological reading (Judeo-Christian, in Western case) that surfaces after the shaping of human nature. We are born neither evil, nor good, nor merely a dumb brute. We are just like all animals unable to perceive much beyond our own universe. We have a pack and survival instinct, unfathomable manipulative desires move us around for ends other than our individual good, our intellect and communal needs help us build shared symbols and connected experience, and we are to adopt multiple codes and technical tools in order to survive in a brutal environment. If I talk about human faults and strengths in this fashion to my fellow humanists, I sense their reluctance to view human nature in a Darwinian light because of the political overtones. Generally speaking, they are more inclined to favour an interpretation of politics through the lenses of civil disobedience and freedom as a supreme value; for them, social utopia is an ethical enterprise.

The concept of freedom as an absolute, unrestricted of any natural limits, is a heritage Jean-Jacques Rousseau bequeathed to his disciples: if men are born free but shackles are everywhere, true and primeval freedom will only bloom after the rejection of civilization and its inherent laws, constraints and regulations. In this sense, Rousseau's ideas, according to 
Roger Scruton (2010), have encouraged a "culture of repudiation" in the works of progressive authors such as Sartre, Foucault and Althusser. But this cult of repudiation has nothing to offer than the "subversion" or "deconstruction" of the present conditions of society - family, customs, property, law, hierarchy, trade, government, institutions. This utopian transhumanist impulse, defined by pure negation, lives on as a crypto-religious belief in a future of perfection awaiting us after the fall of the current state. In contrast, Scruton (2010, p. 10) makes the case for freedom as "an exercise of the "I"" that "comes into being through the "we""; in a word, freedom is achieved through the free and responsible human person accountable to a tradition of civilized liberty (which is not the same as collectivism). As a matter of fact, every civilizing effort to counter the barbarian side of human nature is nothing but a fragile lid covering a more potent stew of drives, impulses, and passions of the great beast within us. In William Golding's classic novel Lord of the Flies (1959), a supposed monster or common enemy, the "beast," cannot be killed either by children, or by adults, or by anyone else. The beast will be alive as long as we live. The beast is within all of us.

As for tradition, it is a reflection of both the accumulated wisdom of our forebears and the maintenance of power and authority. In a sense, it is hard to believe that if we left issues, say, as the immiseration of the poor or the unequal treatment of LGBT people well alone, then they would organically correct themselves. Social injustice and discrimination certainly demand scholarly attention, academic debate, and the execution of goal-directed policies. Still, none of this implies that we can simply ignore or reject the valuable inheritance of earlier generations as a reliable guide for present conduct. A nation, after all, is indeed a contract that "becomes a partnership...between those who are living, those who are dead, and those who are to be born," as wrote Edmund Burke (1986 [1790]), the founder of modern conservatism. So when the academy gives up a fair analysis on the imbalances between the liberalisation of social norms and the weight of time-honoured tradition, it gives up too much, it ceases to be sovereign.

In addition, this intellectual bias is an open flank to many political attacks and lesser funding opportunities. The rise of victimhood culture, oversensitivity paranoia, and shallow intellectual eddies on campus have coincided ominously with much negative media coverage on the humanities' low status, reduced financial aid, and declining student enrolment around the globe (COHEN, 2009, FISH 2010, DELANY 2013, LEVITZ; BELKIN 2013, LEWIN 2013, LOVETT 2014, BUSL 2015). In Japan, more than 50 universities were to close or downsize their humanities sector recently in order to offer a "more practical, vocational 
education that better anticipates the needs of society" (DEAN, 2015). It is not clear yet if the humanists' self-sabotaging beliefs are a ripple effect of the current predicament or vice-versa. Anyway, the plight of the field is real and sad, both financially and epistemologically.

From the above, I hope the reader will understand that it is not my goal to sound alarmist. This reputational damage is no novelty per se. The despondency about the future of the humanities goes far back in time. Paul Benneworth (2015, p. 3-8.) dates the origins of a "crisis" in the humanities to 1964, when the chronic symptom of the "two cultures" of arts and sciences, brought about by Charles Percy Snow, has played out across campuses globally. Authors such as Norbert Elias (1897-1990) were already concerned about the irrelevance of social sciences for not being able to address real-life problems. Edmund Husserl (1859-1938) was persuaded that Europe had by his time entered a profound state of "crisis," not just as a geographical location but in terms of rationality and culture (HUSSERL, 1970, p. 17). And a bit farther back in time, Edmund Burke (1729-1797) was already labelling as "closet theories" the grand ideologies and humanist penchant for unrealistic formula of political redemption.

Matters being thus settled, I would like to proceed, in the next place, with seven salutary warnings for the humanities of the present. These are not to be a code of ethics, but rather a collection of words of advice to inspire the quest for a politically balanced faculty and to attempt humbly to shift the balance more in the direction of rational thinking, open-minded debates, and free speech on campus. Just enough if it be cultivated, and yield fruits.

\section{(1) On the Grand Humanitarian Project and Redemption Cult}

We humanists are heirs of an engaged philosophy. Franco-Swiss philosopher JeanJacques Rousseau is a key thinker and contributor to a re-reading of the myth of the Fall, according to which humans used to live harmoniously in Nature and the emergence of private property put an end to such bliss. From there grow the humanities' deep ties to a romantic aesthetic thought which attributes to the arts a particularly potent force in reforming society and shaping cultural values. The arts are supposed to engage with and commit to a radical change that frees rank and file. Hence the question of the "subaltern." Yet if it would not be too much to ask, does anyone speak for or emancipate someone else? Is there any need for an "anointed" minority to set free an "unenlightened" majority? Even if one rightfully wished to emancipate somebody else, could it be done with commitment to honest criticism and intellectual penetration? Why is it that the Liberation Theology took up the preferential option for the poor, and yet the poor chose to be converts to one or other variant of evangelical Protestantism, which preaches the "theology of prosperity" and stages melodramatic 
exorcisms for chanting believers? Today many humanists are blind to their own bigotry against conservative religion, while exploring unrealistic portrayals of rural folks, working class and poor people.

We humanists have read much a tradition of intellectuals who follow Rousseau's trail, linking politics to either a redemptive future or a mythical past, or both, while authors that discuss de facto politics (management of power) have been entirely put aside. Hence, our emancipatory theses have become an articulated collective delirium, whose relevance speaks more to a grand ethical project or a deontological gesture - in the sense of worshiping what it should be - than to an ontological one - in the sense of realizing what it is. Part of today's anti-establishment anger is vented as a result of what has been repressed by progressive liberal-left academics mesmerised by culturally constructed issues and political correctness.

We need to read more Machiavelli and watch more John Ford.

\section{(2) On the Victimhood Narrative and the Tribalization of the Mind}

To dole out equal justice, one oppression is solved with another inversely and directly proportional to the infringement committed. An eye for an eye. While discussing America's racial issues in an interview, Toni Morrison stated that she wanted to see "a cop shoot a white unarmed teenager in the back" (WOOD, 2015). How much more fortunate would the Nobel Prize winner have been if she had pleased us with something like the introductory lines for one of the Sly \& the Family Stone's songs: "Don't hate the black/ Don't hate the white/ If you get bitten/ Just hate the bite." Instead, facts are distorted, fallacies defended, and obscure prose spread. Now I think of Gloria Anzaldúa's mythopoeic narrative with historical dishonesty and of Judith Butler's mind-bogglingly cryptic meditation on sex and gender. The meaningless mumbo-jumbo of these scholars serves just to obscure their goals and purposes, and to transform their opaque tribal causes into an illusion of respectability.

For the present-day difficulties of my beloved tribe, faulty past agents or events are always to blame. In the opening of 2015, Robert Mugabe, Zimbabwe's divisive president and despotic pariah responsible for countless gross violations of the human rights, assumed as chair of the African Union. By that same time, Evo Morales - dressing a fine vicuna-wool tunic embossed with gold and silver whose cost amounted to 27,000 Boliviano $(\$ 3,900)$ - was inaugurated into his third term as president of Bolivia in a traditional ceremony in the precolonial city of Tiwanaku. (A tribal inauguration is definitely an innovative populist platform to conceal political manoeuvres, deceive, and secure power.) In both events, these righteous 
leaders delivered full anti-imperialist, anti-colonial, anti-capitalist acceptance speeches that would have gladden the hearts of many postcolonial theorists.

Ideological blindness, systemic corruption and ill governance spreads across the world, but countless intellectuals keep endorsing much of it, even in the face of mounting evidence to the contrary. The practical consequence of these biased political narratives can be fatal, especially for the lower-income families who are more dependent on public services. The victimhood culture is the new intellectual panacea for the redemption of all the sins of the world. And its advocates, hiding behind volatile tales of oppression and nebulous arguments dressed up in fancy words, look like the new wolves in sheep's clothing - or in tribe's clothing.

The apostles of identity politics have fallen into a my-tribe-my-rules trap. They see authoritarianism and discrimination in others, but not in themselves. In guarding their chosen tribes, they fail Locke's ultimate test of liberal value, of tolerance for those that are of different opinions and with whom they disagree.

\section{(3) On the Contempt for or Ignorance about the Human Universals}

We humans are complex biopsychosocial beings, and adaptive evolution has endowed us with mental faculties and bodily capabilities to survive and thrive all over the globe. Thus, we share a set of bodily and psychological traits that influence behaviour in group settings across societies and across cultures. "Human universals," as defined by anthropologist Donald Brown (1991, p. 382), “comprise those features of culture, society, language, behavior, and psyche for which there are no known exception to their existence in all ethnographically or historically recorded human societies." These universals can be thus conceptualised as timeless commonalities for they are phenomena occurring in all known human cultures throughout space and time. The adoption of human universal principles by humanists across the board would help slow down the flood of crackpot theories and misleading claims in the academy.

In one of her textual reveries, Donna Haraway seems to be not acquainted with one of the basic elements of human universals:

I will argue below that work, use, and instrumentality are intrinsic to bodily webbed mortal earthly being and becoming. Unidirectional relations of use, ruled by practices of calculation and self-sure of hierarchy, are quite another matter. Such self-satisfied calculation takes heart from the primary dualism that parses body one way and mind another. That dualism should have withered long ago in the light of feminist and many other criticisms, but the fantastic mind/body binary has proved remarkably resilient. Failing, indeed refusing, to come face-to-face with animals, I 
In this passage, Haraway's discernment of mind and body is deceived by a mirage when she argues that such "dualism should have withered long ago in the light of feminist and many other criticisms." Taken literally, this excerpt reads either as a conceptual oddity hoping for the triumph of ideology over reality, or as a wishful thought that cannot talk to the unsurmountable limitations weighing heavily upon the human condition. Neither will Haraway's faith in the face-to-face contact with animals nor any sort of "criticisms" ever do away with this or any other dualism. The reason is simple: dualisms are an inherent part of us. Conceptual binary distinctions, whether natural (light-dark, heat-cold) or constructed (rightwrong, good-bad), hold deep symbolic meanings across all human cultures, and neither pair of opposing poles is more basic than the other. Only Newspeak can forbid or deconstruct it. Even though it is not my frame of mind to think in terms of dualisms, they are here to stay. And to emasculate theory with verbiage so as to "deconstruct," as is the case, the body-mind split in the hope to see it wither and die is far from being a serious approach to reality.

Note, above all, the dualistic pursuit of knowing what is human existence. No one know exactly how to determine human existence. But certainly, something in-between instinctive feeling, faith, and conscious reasoning gets humans in touch to each other, so that they recognize their common existence, their own self, their interdependence with the natural kingdom and so on. We know what the human awareness is and what the human point-ofview is; we are aware of our capabilities and limitations; we know that we are dependent on technical skills and natural resources. The quest for wisdom in many traditions begins with this sensory perception. Nevertheless - and here begin the difficulties in the pursuit of knowing what the human phenomenon is - not all humans provide us with the same definition of what is human existence. That is, what we deem to be human existence can be vastly different from the concept of human existence that many other humans have framed, since the specific roles through which we act in the world differ from society to society. This poses an everlasting rock on the path of philosophical or cultural dialogue, since all cultures inevitably depart from an essence of the nature of our birthright and the gift of our existence. If the lifedeath problem is a human universal - i.e. no known human culture is unaware or unconcerned about it - the kinds of questions that this duality raise in different cultures are not necessarily the same. The same goes for the typical thought-reality, individual-community, male-female, cognition-practice, fact-volition, happiness-misery, duty-desire, and such-like dualisms. These dissimilar questions usually let critical borders stand against the much said but little done 
"intercultural dialogue."

Still, our brains take delight in conflating patterns of dualistic thought, even if dualisms and dichotomous thinking hardly provide us with a decent description of reality (here perhaps lies the oasis that prompted Haraway to chase a mirage). Alas, this is a fault from which human affairs can perhaps scarce ever be perfectly freed. From this, it follows that the idea of human universals should be read not as an absolute and peremptory decree, but rather as a meditation upon the contingencies of tangible reality (body) and moral torments (mind) that afflict all of us, everywhere, every day. As a general rule, this world is consistent; and we ourselves are, too.

\section{(4) On the Distorted Evaluation Criteria and Publish-or-Perish Mantra}

In a recent interview, neuroscientist Suzana Herculano-Houzel, who pioneered a fast and accurate technique to count brain cells, voiced her disappointment over Brazilian universities, which, according to her, are attached to a model of engessamento [stiffening] (LOPES, 2016). In Brazil's academy, this rigid model neither rewards the best scholars for outstanding merit nor punishes the unproductive ones geared more towards job stability than to efficiency. This inflexibility accounts also for bureaucratic shackles on the finance of research inputs and equipment, teaching aids, library facilities, as well as difficulties in getting foreign teachers hired and receiving grant support from foreign organizations. This gloomy scenario heavily influenced Herculano-Houzel's decision to leave the Institute of Biomedical Science at the Federal University of Rio de Janeiro and move to join Vanderbilt University, in Nashville. This stymied progress is rooted in the monstrous hypertrophy of the Brazilian state apparatus, over which prevail patronage and corporatist practices that help undermining, among other things, scientific research and academic innovation. The opportunity costs due to such stiffening forces are hard to quantify, but they are likely to be vast.

It is tempting to see this engessamento as an isolated case in the area of sciences. To think so is to place a bet on the longstanding unproductive opposition between the humanities and natural sciences - a divorce which, according to Isaiah Berlin (1974), took place in the early 18th century. If we can afford to look beyond the political and ideological struggles between hard sciences and soft ones for location, size, grant and prestige, we will find that the School of Humanities is equally impacted by these negative effects.

At liberal-arts colleges in Brazil, it is nearly impossible for a scholar to stop publishing for a while and keep pace with a relevant book-length study, more compatible with 
the public interest. Moreover, a truly first-rate political or philosophical work may take years to be put down on paper. Yet such time-consuming project - furthering our understanding of human knowledge and welfare - is unthinkable under the burden of such bureaucracy. Humanists need therefore to have their achievement recognised through a different set of standards, more in line with the specific requirements of the liberal arts. The humanities are not an exact science and thus should not meet the same standards. If funding bodies are to press faculties for researching in ways that ensure immediate return, then it will become increasingly difficult to undertake humanities research. We waste too much time with an innocuous productivity on behalf of the two major higher education funding agencies, Capes and $\mathrm{CNPq}$, or insisting on writing esoteric papers about non-existent human beings. The demand for a bureaucratically structured lattes curriculum in Brazil together with the endless layers of research red-tape is defeating. Bureaucracy reigns supreme in all academic areas, in the grant application forms and deadlines.

From this, a couple of questions follow: What if we could publish less but more substantial papers and preferably in the most enlightened journals? What if critical acclaim and post-publication evaluation could do much more to advance a lecturer's career? How about including lecturing performance as criteria for tenure and promotion? How about getting rid of thought policing, Newspeak, false reasoning and censorship in the lecture halls, and start promoting taste for self-policing, quality control, verification etc., so as not to let dubious claims and fundamental flaws live on to mislead? If teaching ability was not dismissed altogether in the lecture hall, performance in a classroom would often be seen as more important than scholarship. The peer-review multiple failings would matter less if, in the humanities departments, the mechanism of critical thinking, understanding both sides of an issue, and teacher-correction were in working order.

\section{(5) On the Moral Obligations of the Educator in the Lecture Hall}

Not to abuse the audience of students. Not to favour or harm students for their political, ideological, religious or moral convictions. Not to ignore the skills in fostering the free flow of ideas and essential information among persons of different worldviews. To know indeed that one cannot learn or teach only with ideas, and that there is something out there called Nature that has its own laws and is coldly indifferent to what human ideas and wishes may be. To introduce to the class the main theories, versions, and competing perspectives on any topic when it comes to dealing with controversially scientific issues. Not to commit with currents of thought, but with the higher quality and reputation of the study of the humanities. 
To question oneself and challenge one's own views. To know that the genuine and warm dialogue exists only where divergence arises, and so is expected to be - as the alternative to it borders on subjection, either imposed or voluntary. To raise concerns about the cant of the ideological hypocrite whether in the clergy or in the laity.

To bear in mind that taboos are marked fears about real or imagined situations in life. The policing of taboos and the category of profanity vary from time to time. In medieval era, it was the wrath of God for taking the Lord's name in vain; by the late 18th century, sexual activity, excretion and the bodily parts; today, the slandering of certain groups. Sex or religion is no longer seen as truly profane, but our profanity consists of the defamation of groups, especially those historically discriminated. Thus, for better or worse, we are not much different from our ancestors in terms of word taboos. To bear in mind that the a priori assumption of political correctness has been used, in some cases, as a trench for hypocrisy and idiocy.

\section{(6) On the Humanities' Flaws in the Face of Verifiable Scientific Evidence}

The vast majority of medical and scientific innovations go into the sieve of tests and analyses usually created by a team of subject-matter experts (SMEs). Scientific inquiry generally aims to generate technical products that are verifiable and testable, whose errors are more easily identifiable. If it is not always so, the underlying cause is usually some defective external factor (political, economic, psychological etc.) unrelated to the scientific method itself. In contrast, putting together a picture of how to open the humanities' theoretical black box when we attempt to verify and test the real-life effects of ideas is notoriously more complicated. In Intellectuals and Society (2009), Thomas Sowell has dealt with this theoretical black box in an attempt to get a better idea of what the delusions of conceptual grandeur may signify in practical terms. Intellectuals (or the "anointed," as Sowell calls them) think they understand the world better than the common men who have been sustaining them for millennia. Faith in a wishful thinking strategy of rearranging the world according to their own witticism and design of progress has led many humanists to sign a declaration of intellectual bankruptcy time and again. That has become a significant part of the problem, rather than part of the solution. Hence, Sowell is mainly concerned with the verifiability of ideas as "[t]he impact of ideas on the real world can hardly be disputed" (SOWELL, 2009, p. 7). He notes that the application of many visionary thinkers' ideas (Rousseau, Marx, Engels, Galbraith, Keynes and so on) have led to dire consequences and negative effects, and yet those ideas did not lose credibility among their intellectual peers or target audience. Such 
intellectuals, whether in the media or in the academy, are "unaccountable to the external world," and such unaccountability has become "not simply a happenstance but a principle" (SOWELL, 2009, p. 8). Thus, despite many high-profile intellectuals have been tied to the relentless use of abstractions and empty arguments, they continue to be immune from sanction or loss of reputation after having been proven wrong.

In addition, the prevailing spirit in the humanities nowadays is that emotional reasoning and abstract knowledge can overcome concrete and verifiable information. The pursuit of didacticism, discipline, and uniformity of methods seems to be no longer a cause for concern. Consumed by this fantasy, the risk of the disciplines losing sight of a sense of purpose and meaning in the lecture hall and research activities is high. This, of course, is not to weave praise to scientism or authoritarianism in the humanities. All the same, respect for flexibility and autonomy is not to be confused with theoretical sloppiness and methodological laxity - from which emerges, in the humanities of today, a cascade of teaching methods and research framework fostering innate, intuitive knowledge and emancipatory delusions.

What, then, can be done? What should be high quality research for the humanities? First, this appears to be a half-finished question. Why not ask, how much effort have we put into demonstrating what purpose our work may have beyond the seminar rooms, the campus walls, and the scholarly journals? How often do we explore popular venues for our work? What is the public knowledge of and response to the mass of our work? Is it doubt, disdain, indifference or interest? And how are we developing students' intellectual and social skills? Furthermore, high-quality research is mostly valid, reliable and generalizable. It plays a large role in the reassurance dimension. But the inward-focus of human science research and its failures to dislodge entrenched ideas have left an open flank for common errors of validity. Among them are unsubstantiated observation, speculation, straw-man fallacy, overgeneralization, false-positive/false-negative conclusions etc. Not only scientific findings but also ideas should always be subject to challenge from evidence and experiment. Philosophy and science are innately tied together, and must remain so.

\section{(7) On Faculty Diversity, Fewer Intellectuals and More Educators}

In the world of the humanities, the contingent speaking for academia's classical conservatism and liberalism is a cruelly curbed minority. The inclusion of more liberal and conservative thinkers in the academic disciplines can make the political and philosophical debate on campus more critical and less redeeming. If the goal of recruitment for academic posts is to contribute to the college's diversity, this should be a code not only for ethnicity or 
gender but also for political and intellectual diversity, and thus for some well-balanced curricula. The assembly of a politically diverse faculty in the humanities and social sciences departments would fully serve the goal of promoting greater commitment to a realistic description of the world. Then we could better discuss the problems of a given society and suggest possible action. For far too long, the Humanities Division has been a politically unbalanced territory in which ideological monopolies thrive and crystalized lies are defended.

Humanists need to be more sceptical about the political redemption and social engineering inherited from Rousseau and Marx, and stop thinking that Nature or the existence of this world is dependent on what we think of it. The failure of many academics is therefore not intellectual, but ethical. Socrates has taught us that the problem of knowledge is, above all, ethical. For him, knowledge is to discover one's own ignorance. The only true wisdom is in knowing you know nothing: the more I know I know, I know the less. But what became of the doubt in the humanities? What would Socrates say about this trend in higher education that moves away from asking the fundamental questions that philosophy poses? When some of my fellow humanists pose a question today they do not expect to hear an answer; rather they just want to hear the echo-chamber of their own certainties. And in a world where certainties abound, speculative intelligence easily becomes subversive, and therefore is not welcome.

What we need in the humanities is fewer thought police, fewer intellectuals and more educators. Educators are prone to seek the light of reason and understanding, and to learn how to teach and apprehend, questioning their own ideas to improve them. The Greek philosopher Nikos Kazantzakis once suggested that "Ideal teachers are those who use themselves as bridges over which they invite their students to cross, then having facilitated their crossing, joyfully collapse, encouraging them to create bridges of their own" (ADITHAN, 2014, p. 65). This pairing of teachers and bridges resonates well with Lukianoff and Haidt's proposal that "colleges should do all they can to equip students to thrive in a world full of words and ideas that they cannot control" (LUKIANOFF; HAIDT, The Atlantic 2015). Alas, faculty members and university administrators seem to be taking a step in the opposite direction. Has the illimitable freedom of the human mind as a pedagogical attitude become obsolete? It is for the good educators to raise consciousness about such questions, and also to seek a balance between the need for freedom of speech and the need to make students feel willing to engage in public debates that welcome the discussion of "inflammatory" ideas. 


\section{Coda}

These reiterated warnings are not to be a mantra to the ears of the reader. Nor are they a collection of templates to fix the future of the humanities. Maybe it is too late to turn back the clock. Or at least it is not the best time to be studying the arts and humanities. So I just hope these warnings might feel like a collection of insights for the respectable humanist who seeks understanding, creative questioning, and free spirit against single-mindedness and tunnel vision. A respectable humanist is the one who criticizes his home thanks to what he learned on campus, as well as his college thanks to what he learned at home.

One final point: all the above might lead to the misjudgement of those who assume that my goal here is solely to lambast the left-leaning intelligentsia and to reduce it to a caricature of social engineering and anti-capitalist instincts. No, this is far from being the case in this study. To begin with, though the "leftists" like to identify themselves as such, the very idea of "left" and "right" as a single dimension of factions and opinions within the political order is unacceptable to me. Nor is this about raging firestorm over bigotry in the left-leaning academy. The point is that the "left" (but it could also be the "right") is usually happy enough with all forms of censorship and thought policing on campus whenever it is convenient to push "progressive" agendas. Even after the downfall of all grand ideologies of redemption, the romantic leftist and the equally romantic libertarian continue to falsely believe that the warm milk of decency and ethics is poured down democratically at the birth of the "vanguards". And unless we challenge this thought police trend in the most robust way, whatever kind of university (or country) we end up choosing to live a life in is unlikely to be a free space.

With the advent of the digital revolution and online social networks, the thought police became vast and labyrinthine. With the ease of a creature so in tune with its environment, political hooligans are prowling the streets of campus and of the internet. It is a new form of censorship. Zealous brigades are found among conservatives and liberals, atheists and religious, authoritarian and anti-establishmentarian. Clichés replace debate; subtlety gives way to the flames of moral certainty. And this phenomenon has been defiling the study of the humanities. The humanities are suffering a severe loss of humility, data analysis skill, teaching methodology, and deep thinking. Thinking nevertheless is complex. It requires an accumulation of superior effort and focused execution. Good texts and teaching methods are what make you think. Good thinking is to defend a unique position, with irrefutable, seductive, clear argumentation. Good argumentation is intelligent and is not a 
preserve of any side of the political spectrum. A conservative text can be breath-taking; a leftist one can yield remarkable insights. Karl Marx read and thought a good deal upon the works of Jean-Jacques Rousseau, Adam Smith, David Ricardo, Thomas Malthus, among many others. Thus, Marx will be better understood in closer dialogue with thinkers from various perspectives and political camps. Thinking entails unlearning fixed, ingrained, unquestioned habits of thought.

One glaring "progressive" error at present is the attitude of locking the humanities down on to a one-way road of thinking about human life. In breaking away from the mundane conflicts between conscience and desire, virtue and temptation, or simply good and evil—key drivers of the human moral drama-the Humanities Division has helped reduce the intellectual landscape of the human sciences. Eventually, and sadly, it shrinks away from the edges of the ancient swamps that surround all human beings, thereby understanding less and less of the very human condition. Even if the Area Studies and other interdisciplinary fields seek to accomplish unique and particular missions, certain universal human characteristics should guide higher education developments worldwide. And as the world changes, humanities education should be leading courageously.

And when life hurts - and more often than not it hurts - it is better to bargain with our own demons and to make war upon our own lusts and vices than run into "safe spaces." For wisdom is gained through experiencing different things, including our cruel share of winters. And once it is gained, then it can be handed down. This is what the School of Humanities should strive for.

\section{Acknowledgement}

I am much grateful to Dr. Eloína Prati do Santos for the comments and criticisms she has imparted for the improvement of the Seven Salutary Warnings hereby proposed.

\section{References}

ADITHAN, Dr. M. Study skills for professional students in higher education. New Delhi: S. Chand \& Company, 2014.

BAWER, Bruce. The Victims' Revolution: The Rise of Identity Studies and the Closing of the Liberal Mind. New York: Broadside Books, 2012.

BECKER, Ernest. The Denial of Death. New York: Free Press, 1973. 
BENNEWORTH, Paul. Putting impact into context: The Janus face of the public value of arts and Humanities research. Arts and Humanities in Higher Education. An International Journal of Theory, Research and Practice [S.1.], v. 14, n. 1, p. 3-8, Feb. 2015.

BERLIN, Isaiah. The Divorce between the Sciences and the Humanities. Salmagundi. New York: Skidmore College, n. 27, p. 9-39, 1974.

BLOOM, Allan. The Closing of the American Mind: How Higher Education Has Failed Democracy and Impoverished the Souls of Today's Students. New York: Simon \& Schuster, 1987.

BROWN, Donald. Human Universals. Philadelphia, PA: Temple University Press, 1991.

BURKE, Edmund. Reflections on the Revolution in France. Harmondsworth: Penguin, 1986.

BUSL, Gretchen. Humanities research is groundbreaking, life-changing... and ignored. The Guardian, London, 19 Oct. 2015. URL: <http://goo.gl/z6mLly>. Date Accessed: 20/12/2015.

COHEN, Nick. The idea of a university as a free space rather than a safe space is vanishing. The Spectator, London, 17 Mar. 2016. URL: <http://goo.gl/btCVug $>$. Date Accessed: 20/05/2016.

COHEN, Patricia. In Tough Times, the Humanities Must Justify Their Worth. The New York Times, New York, 25 Feb. 2009. URL: <http://goo.g1/25in6u $>$. Date Accessed: 11/10/2015.

DEAN, Alex. Japan's Humanities chop sends shivers down academic spines. The Guardian,

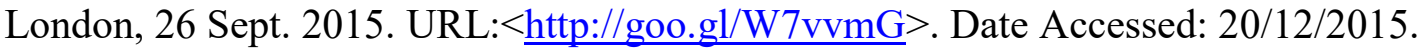

DELANY, Ella. Humanities Studies Under Strain Around the Globe. The New York Times,

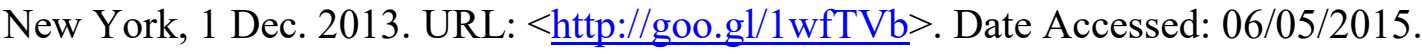

ReasonTV. "Everything's Awesome and Camille Paglia is Unhappy!” Perf. Camille Paglia. Produced by Todd Krainin. Hosted by Nick Gillespie. Cameras by Meredith Bragg and Krainin. 19 Mar. 2015. URL: <https://goo.gl/WcQILu> Date Accessed: 9 June 2015.

FISH, Stanley. The Crisis of the Humanities Officially Arrives. The New York Times, New York, 11 Oct. 2010. URL: < https://goo.gl/X6NK9C $>$. Date Accessed: 20/12/2015.

GOLDING, William. Lord of the Flies. New York: Penguin Group, 1959.

HARAWAY, Donna. When Species Meet. Minneapolis: University of Minnesota Press, 2008.

HUSSERL, Edmund. The Crisis of the European Sciences and Transcendental Phenomenology: An Introduction to Phenomenological Philosophy. Trans. Paul Carr. Evanston: Northwestern University Press, 1970.

LEVITZ, Jennifer; BELKIN, Douglas. Humanities Fall From Favor. The Wall Street Journal, New York, 6 June 2013. URL: <http://goo.gl/xG5F02>. Date Accessed: 13/10/2014.

LEWIN, Tamar. As Interest Fades in the Humanities, Colleges Worry. The New York Times

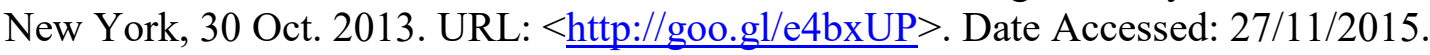


LOCKE, John. The Works of John Locke Esq., in Three Volumes. Vol. II. 5th ed. London: printed for S. Birt, D. Browne, T. Longman, J. Shuckburgh, C. Hitch and L. Hawes [and 7 others in London], 1751.

LOPES, Reinaldo José. 'Engessamento me fez deixar o país', diz a neurocientista Suzana Herculano. Folha de S.Paulo, São Paulo, 5 May 2016. URL: < http://goo.gl/tqEIIh $>$. Date Accessed: 27/05/2016.

LOVETT, Samuel. Is a degree in the humanities no longer appreciated? The Independent , London, 11 Dec. 2014. URL: <https://goo.gl/A1iD32>. Date Accessed: 10/01/2015.

LUKIANOFF, Greg; HAIDT, Jonathan. The Coddling of the American Mind. The Atlantic.

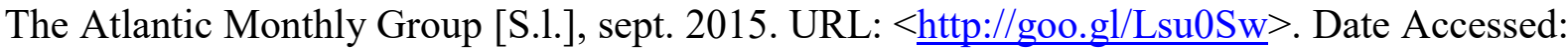
04/062016.

O'NEILL, Brendan. "Free speech is so last century. Today's students want the 'right to be comfortable'." The Spectator, London, 22 Nov. 2014. URL: <http://goo.gl/QO4RZe >. Date Accessed: 30/05/2016.

ORWELL, George. "Politics and the English Language." in The Collected Essays, Journalism and Letters of George Orwell. Vol. 4. Eds. Sonia Orwell and Ian Angus. London: Penguin Books, 1968.

SCRUTON, Roger. The Uses of Pessimism: And the Danger of False Hope. Oxford; New York: Oxford University Press, 2010.

SOWELL, Thomas. Intellectuals and Society. New York: Basic Books, 2009.

VIVANCO, Leonor; RHODES, Dawn. U. of C. tells incoming freshmen it does not support 'trigger warnings' or 'safe spaces'. Chicago Tribune, Chicago, 25 Aug. 2016. URL:

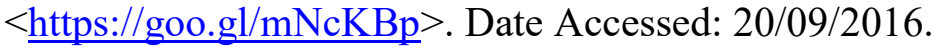

WOOD, Gaby. Toni Morrison interview: on racism, her new novel and Marlon Brando. The Daily Telegraph London, 19 April 2015. URL: <http://goo.gl/pPJT1n>. Date Accessed: 27/07/ 2015.

\section{Sete alertas saudáveis para as humanidades: um breve vislumbre da faceta mais trágica das artes liberais hoje}

Resumo: Uma dizimação das artes liberais está em curso. O estudo das humanidades tem declinado acentuadamente em todo o mundo na última década, e isso vem seguido de uma combinação terrível de crises internas e externas. Por um lado, a queda no financiamento e a ascensão da tecnologia e dos negócios estão desempenhando um papel vital nessa ruína; por outro, a própria alma das artes e dos estudos culturais está cada vez mais distante dos valores centrais do pensamento liberal. Os departamentos de humanas estão sendo invadidos pela cultura da vitimização, modelos pedagógicos disfuncionais e um sério enfraquecimento do bem comum e da liberdade de expressão. Resgatar as humanidades deste atoleiro não é tarefa fácil, mas é algo que precisa ser feito logo, pois a supremacia da ciência e da tecnologia não é uma garantia de direitos naturais a nenhuma nação. Nesse sentido, o objetivo deste ensaio é traçar um breve panorama das principais razões pelas quais as humanidades caíram em desgraça. Olhando especialmente para os fatores internos de autossabotagem, sete alertas 
saudáveis serão discutidos como incentivos para a tomada de decisões nos departamentos. Sobretudo, não limitar a análise da natureza e dos assuntos humanos ao relativismo epistemológico pós-moderno e às teorias construtivistas radicais já significaria um pequeno avanço. Mas mudanças mais drásticas precisam ser feitas. A área de Humanidades precisa se livrar, entre outras coisas, de sua rigidez institucional e das vicissitudes de ideologias redentoras. Um currículo mais diversificado e um quadro docente mais politicamente equilibrado têm de ser perseguidos. E o método socrático de ensino-aprendizagem poderia funcionar como um antídoto para o mal-estar disciplinar na academia atual.

Palavras-chave: Ensino Superior. Humanidades. Intelectualidade. Vida no Campus. Desafios Políticos.

Recebido: 03/12/2016

Aceito: 05/05/2017 